\title{
Refuge
}

Canada's Journal on Refugees

Revue canadienne sur les réfugiés

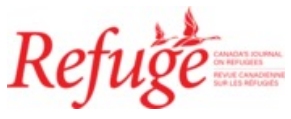

\section{Volunteering to Support Refugees: A Question of One's Scope of Justice}

\section{Elisabeth Kals and Isabel Theresia Strubel}

Volume 33, Number 2, 2017

URI: https://id.erudit.org/iderudit/1043064ar

DOI: https://doi.org/10.7202/1043064ar

See table of contents

Publisher(s)

Centre for Refugee Studies, York University

ISSN

0229-5113 (print)

1920-7336 (digital)

Explore this journal

Cite this article

Kals, E. \& Strubel, I. (2017). Volunteering to Support Refugees: A Question of One's Scope of Justice. Refuge, 33(2), 66-77. https://doi.org/10.7202/1043064ar
Article abstract

Who volunteers on behalf of refugees, on the basis of what motives? Questionnaire data $(\mathrm{N}=271)$ reveal that people who volunteer, and those who do not, share differentiated perceptions of fairness about refugee aid. However, volunteers have a broader and more inclusive scope of justice than a matched group of non-volunteers. The scope of justice proves to be a powerful construct when explaining the willingness to volunteer beyond group membership (volunteers vs. non-volunteers) and the functional approach. Perceptions of fairness, especially the scope of justice, should therefore be considered in order to understand differences in reactions towards refugees if moral exclusion is to be avoided.
Copyright (c) Refuge: Canada’s Journal on Refugees, 2017

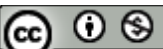

This document is protected by copyright law. Use of the services of Érudit (including reproduction) is subject to its terms and conditions, which can be viewed online.

https://apropos.erudit.org/en/users/policy-on-use/ 


\title{
Volunteering to Support Refugees: A Question of One's Scope of Justice
}

\author{
ELISABETH KALS AND ISABEL THERESIA STRUBEL ${ }^{1}$
}

\section{Abstract}

Who volunteers on behalf of refugees, on the basis of what motives? Questionnaire data $(\mathrm{N}=271)$ reveal that people who volunteer, and those who do not, share differentiated perceptions of fairness about refugee aid. However, volunteers have a broader and more inclusive scope of justice than a matched group of non-volunteers. The scope of justice proves to be a powerful construct when explaining the willingness to volunteer beyond group membership (volunteers vs. non-volunteers) and the functional approach. Perceptions of fairness, especially the scope of justice, should therefore be considered in order to understand differences in reactions towards refugees if moral exclusion is to be avoided.

\section{Résumé}

Qui fait volontairement du bénévolat en faveur des réfugiés et pour quels types de motifs? Les résultats d'un questionnaire $(\mathrm{N}=271)$ mettent en évidence que les bénévoles et les non-bénévoles ont des perceptions différentes de ce qui est équitable en matière d'aide aux réfugiés. Cependant, les bénévoles ont une vision plus large et plus inclusive de la justice que les non-bénévoles d'un groupe apparié. La portée de la justice démontre ainsi quelle constitue un puissant construit quand on cherche à expliquer le désir dêtre bénévole, au-delà de l'appartenance à un groupe (bénévoles par rapport à non-bénévoles) et d'une démarche fonctionnelle. Les perceptions déquité, la portée de la justice en particulier, devraient ainsi être envisagées pour comprendre les différences de réactions envers les réfugiés, si le facteur "exclusion morale» doit être écarté.

\section{Introduction}

7 here is a worldwide movement of refugees. The German Federal Foreign Office estimates that 65 million are displaced persons. ${ }^{2}$ People from Syria and other regions such as northern Africa, Afghanistan, and Iraq are trying to emigrate, due as the result of migration movements in Africa, the Syrian crisis and their affected neighbours, and the terror organization "Islamic State." Approximately 4.2 million Syrians have become displaced since the civil war began in 2011. ${ }^{3}$ In 2015 the number of refugees worldwide exceeded all annual figures since the end of the Second World War, half of these refugees being minors needing special protection. The main causes of the exodus are violent conflicts, eroding state structures, insufficient economic prospects, and high population growth combined with a lack of resources. 4

Germany, where the research for this article was conducted, has decided to host a relatively high number of refugees in relation to its size. ${ }^{5}$ However, for many years it was not considered a "classical immigration country" and it was only in 2005 that the German government formally recognized Germany as such. ${ }^{6}$ Postwar migration in Germany started in the 1950s. Since then 4.5 million of German heritage ("ethnic German resettlers") have migrated to Germany from the former "Eastern bloc," often fleeing discrimination or persecution.7 From 1955 on, labour migration to West Germany was actively planned for "guest workers." 8 In the late 1980 and the early 1990 o a high number sought asylum in Germany, mainly as a result of the Balkan war, leading to an all-time record migration level in 1992, when the number of immigrants reached 440,000.9 Attitudes toward and acceptance of refugees arriving in the current wave differ from the first two historical migration waves, since the exodus is unplanned, 
partly uncontrolled, and based mainly on international laws and a sense of moral obligation. The sheer numbers also differ from migration levels during the Balkan war. Analyses of numbers for the record year 2015 show that immigration to Germany peaked with more than one million refugees. In 2015 German Chancellor Angela Merkel opened Germany's frontiers to its eastern neighbours to avoid a human catastrophe. On a political level, the question of how to deal with the situation-triggered by the decision to provisionally open the borders-has led to a highly controversial political debate. This has triggered a wide range of reactions among the population: some vehemently oppose admitting the refugees and regard the influx as a threat, whereas others see it as a dual benefit-for the refugees as well as for the host country, its society and economy. In response, stricter laws such as the "Integration Act" entered into force in August 2016, ${ }^{10}$ and Germany boosted its efforts to support the key countries of origin and main transit states. For example, Germany became the third-largest unilateral donor of humanitarian support to Syria and its neighbouring countries, donating more than two billion euros. ${ }^{11}$

The challenges posed by the large-scale immigration of refugees can be met more easily if the majority in the host country is willing to accept the refugees and is prepared to volunteer to assist with their integration. An increasing percentage of people are doing just that. ${ }^{12}$ The Institute for Empirical Integration and Migration Research in Berlin reveals that the majority of organizations dealing with refugee aid reports an average increase of organized volunteers of 70 per cent. ${ }^{13}$ The German Institute for Economic Research states that for the majority of the German population the risks of hosting refugees outweigh the gains, yet four out of ten are generally willing to volunteer to support refugees. ${ }^{14}$ In May 201611.9 per cent of the German-speaking population over the age of 14 volunteered in some way to assist the refugees. Excluding the financial and material support given, still 8.7 per cent of the population purely volunteered, ${ }^{15} \mathrm{a}$ significant increase in comparison to 2014. This leads to the psychological issues at the core of this article: What are the motives behind the willingness to volunteer?

The answer to this question is crucial, not only with regard to a scientific understanding of volunteering but also to political debates and decisions: volunteering processes are being analyzed in an unprecedented, historical era of fundamental change in the world that involves extraordinary challenges for Germany. Conducting research in such a context not only results in a better scientific understanding of volunteering but is also of considerable political significance, since direct recommendations can be put forward, enabling political institutions to deal more effectively with the challenges and to motivate people to constructively support the immigrants.

It is assumed that attitudes toward fairness, in other words, one's scope of justice, can contribute to answering these questions. This newly introduced approach combines with the well-established functional approach to volunteering. Together they form the theoretical basis for the research study presented below.

\section{Justice Research and the Scope of Justice}

The terms refugee and migrant describe people who move from their home country to another. Refugees flee armed conflict or persecution and are protected under international law, whereas migrants move voluntarily to improve their lives. ${ }^{16}$ There are many reasons for legal migration and mobility, such as economic migration, reuniting families, and study and research opportunities, on the one hand, and the demand for international protection and asylum on a national and European level, on the other. Unaccompanied minors and other vulnerable groups also play a special role. ${ }^{17}$ In the UNHCR text, quoted above, as well as in the underlying study, the term refugee is used, since in the German political debate it is this term that is used primarily to define nonWestern immigrants coming to Germany in the context of the above-mentioned migration movements. Moreover, it is impossible to make a clear distinction between refugee and migrant without knowing a person's individual situation.

It is assumed that a sense of justice plays a major role in justifying volunteering as well as the opposite: objections towards refugees. This moral dimension of the question of how a country and its people deal with refugees is also reflected in the public discussion. On the basis of an altruistic and universalistic moral theory, ${ }^{18}$ it is morally commendable that people in existential distress be helped by sharing goods, which is also in line with Kant's categorical imperative. However, whether the inhabitants of the accommodating countries share this opinion and are willing to accept and integrate the newly arrived seems to be a question of justice and especially of one's individual scope of justice. ${ }^{19}$ To what extent are refugees morally excluded or included and perceived as outside or inside the boundaries in which moral values, rules, and considerations of fairness apply? Integration and accompanying aid imply side effects, such as the sacrifice of time and effort, financial costs, political risks. These side effects need to be weighed and may lead to other forms of unfairness und inequality, such as the unequal distribution of financial and immaterial costs incurred in supporting refugees to the large extent currently experienced. Whether the integration of refugees is regarded as a dual benefit seems to depend on how the situation and the refugees are viewed. 
Empirical literature reveals that competition for resources leads to negative attitudes toward refugees and immigration, such as in North America. ${ }^{20}$ Above all, it is the zero-sum competition between groups that has such strong negative influences; the zero-sum competition can be situationally induced or result from a constant, unquestioning belief in zero-sum relations.

These selected examples of the current moral debate on the refugee movement already reflect the significance of the justice dimension. People tend to worry about justice when social conflict occurs, such as in allocation problems, triggering feelings of injustice. ${ }^{21}$ Numerous other normative justice questions could be raised in this discussion and could be debated from a theoretical perspective. Such normative perspectives are indeed taken into consideration here, but the current article is based on an empirical perspective, focusing upon individual judgments on justice and injustice with regard to the refugee movement and the willingness to volunteer to support refugees, regardless of the costs involved.

In Germany volunteering to assist refugees is of immense political importance, as a great number of refugees need to be integrated into society. ${ }^{22}$ The general population plays an important role, perhaps a key role, in enabling this task to be fulfilled. It is a question of being willing to welcome and integrate refugees ${ }^{23}$ into the community, involving physical, social, and psychological integration. ${ }^{24}$ Such help can consist of "one-off" support, such as the provision of equipment (clothing and other donations in kind) and financial aid, as well as regular time-consuming support, including language courses or helping refugees in their daily lives in the new country and culture. Language skills are key to integration and can best be learned by attending language courses, enhanced by everyday contact with local people. ${ }^{25}$

Volunteering covers such practical material assistance, as well as immaterial support for refugees, and is defined as "voluntary, sustained, and ongoing helpfulness." ${ }^{26}$ It should be differentiated from spontaneous helping, whereby the helper is confronted with an unexpected call for help, yet it shares its altruistic motivations. ${ }^{27}$

It has been empirically shown that the justice motive is relevant for social volunteering. ${ }^{28}$ This should also apply to social volunteering for aiding and integrating refugees: what judgments are made, and what categories of fairness are applied to the refugees?

This can be reframed as a question of "scope of justice." This concept was introduced by Opotow. On the basis of and inspired by Deutschs original contribution, ${ }^{29}$ Opotow developed the idea that there are individual and situational differences in the extent to which justice is perceived to be relevant. The scope of justice is defined as the psychological fairness boundary, implying the application of moral values, rules, and justice considerations to those individuals, groups of people, animal species, or other general entities seen within this boundary. Thus, the scope of justice is "the psychological boundary within which considerations of fairness govern our conduct." 30 Entities that are perceived as inside the boundary are regarded as morally included, whereas those outside the boundary are morally excluded. Opotow conducted many exploratory studies in which she observed the effects of moral inclusion and exclusion ${ }^{31}$ and applied the concept to important action fields. ${ }^{32}$ Together with other authors who implemented the construct, which includes exclusion of Haitian refugees 33 and mass internment, ${ }^{34}$ it was shown that entities that are excluded from the scope of justice are vulnerable to harmful treatment. ${ }^{35}$ They are seen as "nonentities," 36 expendable or undeserving, leading to social problems and conflicts.

There is a considerable literature on attitudes toward disadvantaged groups, ${ }^{37}$ but only very few studies aim to apply the scope of justice to minorities: in the context of $9 / 11$, Coryn and Borshuk ${ }^{38}$ investigated to what extent Muslim U.S. Americans are considered to be within the scope of justice of non-Muslim U.S. citizens. The data show that only about one-third of the sample feels that the Muslim Americans are within their scope of justice. In line with this finding, Lima-Nunes, Pereira, and Correia ${ }^{39}$ were able to show that the relationship between prejudice against immigrants in general and discrimination against them is mediated by a restricted view of the scope of justice.

\section{Conceptualization of the Scope of Justice}

The conceptualization of the scope of justice is sometimes regarded as a continuous and sometimes as a dichotomous construct. 40 As a dichotomous construct, entities would either be included or excluded from one's scope of justice; as a continuous construct, the inclusion and exclusion criteria can be expanded, and the boundaries are relative. In our article we have opted for the continuous approach, as the belief that fairness considerations should be applied seems to depend on the extent to which this takes place in practice. This decision is also in line with empirical justice research that usually assesses justice judgments on a continuous scale, varying, for example, from strong agreement to strong disagreement. ${ }^{41}$

Moreover, in some empirical studies the scope of justice is constructed as a mediator variable, which mediates the impact of neediness and similarity on behavioural outcome variables, such as environmental protection..$^{42}$ However, this mediating process has not been sufficiently investigated, and measurement of the construct needs clarification. 43

The core of the construct is the attitudinal belief that considerations of fairness are applied to other groups or entities. 
It reflects to what extent refugees should be treated equally to the people of the host country and have equal legitimate claims. This seems to be one crux of the question regarding the degree to which refugees should be accepted and integrated, since there are limits to the material and nonmaterial goods allocated. Gains by one group might be seen as losses for other groups.

In Opotow's quantitative empirical work 44 the behavioural implications of the justice boundaries comprise the willingness to make sacrifices to foster the other's well-being and to allocate resources to the other. Hafer and Olsen 45 argue in their analysis of empirical research on the scope of justice that its operationalization should not be confused with other constructs; in fact, the application of the fairness rules constituting the core construct does not necessarily lead to positive reactions toward a particular entity. Thus, this core construct is regarded as the "scope of justice." The willingness variables serve as the behavioural validation of this construct.

\section{Functional Approach to Volunteering}

The second theoretical approach is offered by research on volunteering, which has a long tradition, ${ }^{46}$ especially in the context of social relationships. ${ }^{47}$ The most prominent method used to explain current and potential volunteering is the functional approach by Clary et al. ${ }^{8}$ Based on Katz, 49 the functional approach starts from the assumption that certain types of volunteering can fulfil different functions for the volunteer simultaneously. In this respect, the same attitudes can serve various functions for different people within the context of volunteering. In the light of the altruism-egoism discussion these functions can serve the interests of the community and those of the individual volunteer. Assuming that voluntary work can satisfy different motives simultaneously, the approach differentiates between six functions: ${ }^{0}$

1. Value function, which represents an altruistic concern for others; by volunteering, people are able to express values related to altruistic and humanitarian concerns for others;

2. Understanding function, which comprises gaining new skills and knowledge through the volunteering experience as well as the opportunity to exercise knowledge, skills, and abilities;

3. Social function, which reflects motivations involving relationships with others and the normative influence of others, including opportunities to be with one's friends or commit to activities that are also seen as important by significant others;

4. Career function, which is concerned with careerrelated benefits, such as preparing for a new career or acquiring career-relevant skills;
5. Protective function, which means shielding the ego from negative emotions and experiences; volunteering may help to reduce guilt and to address one's own personal problems; and

6. Enhancement function, which involves a motivational process involving the growth and development of the self, including the growth of one's own self-esteem; in contrast to the protective function, this enhancement dimension involves an active positive ambition to develop one's ego.

These six functions have been validated in many studies by the original authors, as well as by the wide range of international literature referring to volunteering in various contexts ${ }^{51}$ and using different forms of conceptualization..$^{52}$ The multiple specific motives defined above show that the simple differentiation of "egoistic" versus "altruistic" motives is outdated; 53 thus, the dichotomous approach should be replaced by the multiple motive approach.

Important empirical studies can also be found on refugees and volunteering, with some studies linking the question of immigration with justice. 54 The current wave, described in the introduction, is quite new, and although research is taking place, few studies have been published. Nevertheless, the broad relevance of the functional approach in the form of the Volunteer Functions Inventory means this approach can be applied to volunteering for refugees.

\section{Integrative Approach and Hypotheses}

Volunteering for refugees comprises two aspects: a general willingness to volunteer as well as actual volunteering on behalf of refugees in organizations ("volunteers"). The willingness to volunteer does not refer to individual behaviour but indicates a general willingness to volunteer in various ways (ranging from public political statements to private everyday help and support). These willingness criteria have proved to be valid proxies of current behaviour revealed in a longitudinal study, especially if situational and social conditions promote the behavioural transfer, as in the positive modelling of friends and significant others. ${ }^{55}$ These criteria are assumed to be explained by the functional motives in the approach by Clary et al..$^{6}$ The scope of justice supplements these motives.

The willingness to make sacrifices to foster the other's well-being as well as the willingness to allocate resources constitute the behavioural dimensions of the scope of justice, which are used as further validation criteria.

We are mindful of the fact that originally Opotow formulated a moderation hypothesis on the effect of the scope of justice. However, in our approach, the scope of justice variable has a different status: Its direct explanatory power should be tested and weighted against the power of the functional variables of Clary et al. 
Three hypotheses are derived:

1. Differentiated justice judgments concerning the scope of justice for refugees are made among the general population. The scope of justice intercorrelates with the two willingness variables as behavioural correlates.

2. The controversy results in significant differences between the volunteers and a matched sample of nonvolunteers on the scope of justice and its two behavioural correlates.

3. The functions of the Volunteer Functions Inventory of Clary et al. can explain why people volunteer on behalf of refugees. The scope of justice defined by Opotow proves to be a powerful construct to explain the willingness to volunteer beyond group membership (volunteers vs. non-volunteers) as well as the functional approach.

\section{Methodology: Sample}

To test the hypotheses, an online survey was conducted with a convenience sample of the overall population as well as a criterion group of volunteers. The overall sample of $N=271$ was recruited in two ways: by means of a snowball principle using social networks, so as to reach people with different opinions on the current migratory situation (non-volunteers $n_{1}=198$ ), as well as by contacting voluntary organizations supporting refugees that aim to recruit volunteers (volunteers $n_{2}=73$ ). With nine missing values, women (166) are overrepresented compared to men (96). The average age is 30.31 (ranging from 16 to 76 , with a standard deviation of 12.31). The educational level is above average.

The average age of the volunteers $\left(n_{2}\right)$ is 32.01 , which is slightly higher than in the overall sample, and the percentage of women is significantly higher than men ( 52 women as opposed to $18 \mathrm{men}$ ). The educational level is even higher than in the overall sample.

In order to compare the group of volunteers and nonvolunteers ( $\mathrm{H} 2$ ), a sample matched according to size, age, sex, and educational level was used $(n=2 \times 73)$.

\section{Measurement Instruments}

All variables were measured using several six-point answering scaled items (ranging from $1=$ strong disagreement to $6=$ strong agreement). Preventive measures were taken to avoid socially desirable answering behaviour, such as a guarantee of anonymity, and the content of the constructs and their item formulation were balanced, e.g., by integrating outrage about excessive refugee aid, appeals to honesty, and admissions about the scientific character of the study. Furthermore, the effect of socially desirable answering behaviour was controlled by integrating the validated short scale of Kemper et al. 57 The six-item scale covers the exaggeration of positive and the understatement of negative qualities and also uses a six-point Likert type answering scale.

All scales were factor analyzed by principle axis analyses with subsequent varimax rotation. The factorial structures presented below are based upon the whole sample and were successfully cross-validated within the subsamples of volunteers and non-volunteers.

The Volunteer Functions Inventory (VFI) was measured using the German translation of the instrument by Oostlander et al. ${ }^{58}$ which was successfully applied in many studies by our research group. In the current study, we used a short version of the inventory. A four-factor solution was found with the aid of the protection and enhancement function, as well as values and understanding loading based on the same factor. This is in line with the factor structures reported by Clary et al., who present for their original six functions a five-, six-, and seven-factor solution, showing that items of various factors are loaded together on the same factor. This is especially the case for the protective and enhancement items. The four-factor solution leads to good reliability with Cronbach's alphas as an estimation index of intern consistency ranging from .83 (value and understanding function) to .89 (career function).

The scope of justice was measured according to three items with Cronbach's alpha of .90:

1. "Refugees should be treated as fairly as all other fellow citizens."

2. "The same justice standards should be applied to refugees as to all other citizens."

3. "Refugees have the same right to be treated fairly as all other citizens."

The behavioural correlates lead to Cronbach's alpha of .85 (willingness to make sacrifices; item example: "I am willing to make financial sacrifices for the well-being of refugees"), and .92 (willingness to allocate resources; item example "Our society must provide the necessary resources so that refugees can live here").

Eleven items measured the various aspects of the willingness to volunteer for refugees during the following year (item example: "In principle, I am willing to participate in actions in favour of refugees, by donating/collecting clothes or toys"). The items loaded on the same factor with a Cronbach's alpha of .93 .

Items of the same factor were summarized, and a mean score of the corresponding items was computed. The following results are based on these newly computed complex variables. 


\section{Descriptive and Correlational Results of the Scope of Justice (Hypothesis 1)}

The scope of justice as an overall variable leads to a high agreement score within the total sample (see table 1).

Although the willingness to make sacrifices for the sake of the refugees is also highly prevalent, the mean value of this variable is clearly lower. The mean value of the willingness to allocate resources lies between these two statistical values. The standard deviations of all three variables are quite high.

High correlations with the scope of justice can be found in the total sample as well as in the groups of volunteers and non-volunteers (see table 1). This is also true when the effects of socially desirable answering behaviour are partialled out.

\section{Differences between Volunteers and Non- Volunteers in the Scope of Justice (Hypothesis 2)}

As table 2 shows, volunteers and the matched group of nonvolunteers differ in the scope of justice variable, as well as in the two willingness variables: volunteers include refugees significantly more into their scope of justice. The highest scores resulted from the willingness to make sacrifices for the well-being of the refugees. This is in line with the willingness to volunteer in favour of refugees (see table 2).

\section{Explanation of the Willingness to Volunteer on Behalf of Refugees (Hypothesis 3)}

Hierarchical regression analyses were conducted to explain the willingness to volunteer on behalf of refugees and to analyze the relative weighting of the scope of justice variable and the different functions of the vFI.

The first predictor block includes the group membership (volunteers vs. non-volunteers); the second the volunteer functions and the third the scope of justice. Together, these variables explain 57 per cent of the criterion variance with a 14 per cent incremental variance due to the scope of justice (see table 3a).

The value and understanding function becomes highly significant. If measures of socially desirable answering behaviour are integrated in the first predictor block, the equations remain stable (see table $3 b$ ).

In sum, the scope of justice plays a major role in the explanation for the willingness to volunteer on behalf of refugees.

\section{Discussion}

Beyond the applicability of the functional approach, the power of the scope of justice is confirmed: within the sample, fairness motives in refugee aid are frequently and differentially expressed. Nevertheless, there is a variation in the valuations, especially in the motive valuations. People who volunteer for refugee aid differ from a matched group of non-volunteers in their corresponding scope of justice. The question, to what extent the same justice claims should be applied to refugees as to all other citizens, is a crucial distinction between the groups. In line with previous findings, the use of the Volunteer Function Inventory (VFI) for volunteers and non-volunteers could be validated for this field of volunteering. Scope of justice explains a significant part of the variance within the willingness to volunteer for the sake of the refugees, beyond the traditional functional motives and group membership.

The newly applied scope of justice construct has proved to be relevant for supporting refugees, confirming earlier results.59 For a further peaceful development in the hosting country but also for international development and peace building, it is helpful to regard immigration as a nonthreatening process with dual benefits, which has occurred repeatedly in history. Yet there are significant differences from earlier postwar immigration processes in Germany, as described above. However, it is important to know that 12 per cent of the German population is volunteering to assist refugees, which constitutes a significant segment of the population, even though roughly 88 per cent of the population is not yet volunteering. ${ }^{60}$ The latter group also needs to be reached. Individual worries about zero-sum beliefs ${ }^{61}$ or national security interests, ${ }^{62}$ a constructive management process to deal with this political situation and the consequences for those affected, create a moral demand based on international law and civil rights. ${ }^{63}$

Therefore a public political debate should be held on the philosophical and legal level of morality, but also on the level of individual perceptions of justice: obviously, people care about fairness and make differentiated judgments on the situation of refugees. Their individual scope of justice is related to their willingness to volunteer. Empirical literature gives guidance on how this scope of justice can be expanded and broadened. Perspective-taking seems to be one key approach to broadening the scope of justice and reaching moral inclusion, or rather, as Opotow says, "If a single cure for moral exclusion exists, it is probably a pluralistic perspective." ${ }^{4} \mathrm{On}$ an emotional level, such perspective taking evokes empathy as a powerful motivation for altruistic behaviour. ${ }^{65}$ To overcome the specific difficulties of perspective-taking, which is the core of such pluralistic thinking and attitudes, the literature offers concrete support and techniques, which are embedded in the context of moral development. ${ }^{66}$ In line with this development, the goal is to overcome stereotypes, distrust, hostility, and-the key construct-moral exclusion. Such a development can be viewed as a learning experience and calls for public debate but also necessitates cultivating dialogue, listening to personal narratives, as well as sharing mutual aims and projects. ${ }^{67}$

Research aiming to overcome stereotypes and moral exclusion is also of great value when studying refugees. In 
Table 1. Descriptive statistics and intercorrelations within the overall sample (total; $N=271$ ), the volunteering subsample (vol; $n_{1}=73$ ), the non-volunteering subsample (non-vol; $n_{2}=198$ ), and the matched non-volunteering subsample (non-vol $[m] ; n_{3}=73$ )

\begin{tabular}{llcrrrr}
\hline Variable & Sample & $M$ & $S D$ & 1 & 2 & 3 \\
\hline Scope of justice & Total & 5.37 & 0.97 & $(.90)$ & $.66^{* *}$ & $.79^{* *}$ \\
& Vol & 5.63 & 0.69 & $(.93)$ & $.51^{* *}$ & $.65^{* *}$ \\
& Non-vol & 5.27 & 1.04 & $(.89)$ & $.67^{* *}$ & $.80^{* *}$ \\
& Non-vol $(\mathrm{m})$ & 5.30 & 1.07 & $(.88)$ & $.73^{* *}$ & $.87^{* *}$ \\
Willingness to make sacrifices & Total & 4.37 & 1.21 & & $(.85)$ & $.80^{* *}$ \\
& Vol & 5.00 & 0.76 & & $(.66)$ & $.63^{* *}$ \\
& Non-vol & 4.13 & 1.26 & & $(.85)$ & $.82^{* *}$ \\
Willingness to allocate resources & Non-vol $(m)$ & 4.29 & 1.16 & & $(.85)$ & $.76^{* *}$ \\
& Total & 4.98 & 1.14 & & & $(.92)$ \\
& Vol & 5.36 & 0.74 & & & $(.85)$ \\
& Non-vol & 4.84 & 1.23 & & & $(.92)$ \\
& Non-vol $(m)$ & 5.00 & 1.21 & & & $(.94)$ \\
\hline
\end{tabular}

Note. All variables range from 1 to 6 with a higher value indicating a stronger agreement.

${ }^{*} p<.05 .{ }^{* *} p<.01$.

Table 2. Mean differences between volunteers and non-volunteers $(n=2 \times 73)$

\begin{tabular}{|c|c|c|c|c|c|c|c|}
\hline Variable & \multicolumn{2}{|c|}{ Vol } & \multicolumn{2}{|c|}{ Non-vol } & $t$ & $d f$ & $d$ \\
\hline Scope of justice & 5.63 & 0.69 & 5.30 & 1.07 & $2.23^{*}$ & 122.95 & 0.37 \\
\hline Willingness to make sacrifices & 5.00 & 0.76 & 4.29 & 1.16 & $4.38^{* *}$ & 124.11 & 0.72 \\
\hline Willingness to allocate resources & 5.36 & 0.74 & 5.00 & 1.21 & $2.21^{*}$ & 119.41 & 0.36 \\
\hline
\end{tabular}

Note: All variables range from 1 to 6 , with a higher value indicating a stronger agreement.

${ }^{*} p<.05 .{ }^{* *} p<.01$ (unilateral testing, including the Bonferroni correction).

a longitudinal field study, for example, attitudes, including prejudice, negative emotions, and discriminatory intentions, were measured before and after the opening of a refugee centre in Germany. ${ }^{68}$ Many living in the neighbourhood initially opposed the opening of the centre. However, it was shown that all kinds of contact (brief encounters, as well as personal or even extended contact) had positive effects on attitudes towards the refugee group. In line with the "mere exposure" hypothesis of Zajonc, ${ }^{69}$ even "mere contact" decreased prejudices and discriminatory intentions over time.

Taking these empirical findings and the high inter-correlations between the scope of justice and a willingness to volunteer to support refugees into consideration, it is likely that they influence one another: on the one hand, a wide scope of justice positively influences the willingness to volunteer; on the other, actual volunteering might widen the scope of justice. Explanatory and moderation variables, such as mere contact, positive experiences with refugees, and personally experienced similarities might account for these effects. These hypotheses will have to be tested.

In principle, conflicts of interests should not be seen as win-lose struggles, since zero-sum competition is counterproductive. ${ }^{70}$ Instead, conflicts of interests should be seen as an opportunity for a win-win situation with dual benefits. This allows a variety of perspectives and mutual interests to become effective. Resources need to be divided fairly, and that can be done in the light of the knowledge that the existence and relevance of a universal justice motive is confirmed in practice..$^{71} \mathrm{~A}$ mutual perspective, based on the understanding of each actor's motives, and by questioning the inclusiveness of national identity helps to overcome narrowmindedness ${ }^{72}$ and paves the way for mutual gains and profits. 
Table 3a. Hierarchical multiple regression of willingness to volunteer on group membership (step 1) (volunteers coded as 1), volunteer functions (step 2), and scope of justice (step 3)

\begin{tabular}{|c|c|c|c|c|c|c|}
\hline & Predictor & $R^{2}$ & $B$ & $S E(B)$ & ß & $r$ \\
\hline \multirow[t]{2}{*}{ Step 1} & Group membership & .13 & 0.95 & .15 & $.37^{* *}$ & .37 \\
\hline & Constant & & 3.97 & .08 & & \\
\hline \multirow[t]{6}{*}{ Step 2} & Group membership & & 0.67 & .13 & $.25^{* *}$ & .37 \\
\hline & Career function & & -0.04 & .05 & -.04 & .06 \\
\hline & Value and understanding function & & 0.66 & .06 & $.55^{* *}$ & .58 \\
\hline & Social function & & 0.09 & .05 & .10 & .37 \\
\hline & Protective and enhancement function & .43 & -0.12 & .06 & -.10 & .10 \\
\hline & Constant & & 1.17 & .26 & & \\
\hline \multirow[t]{7}{*}{ Step 3} & Group membership & & 0.58 & .11 & $.22^{* *}$ & .37 \\
\hline & Career function & & 0.02 & .04 & .02 & .06 \\
\hline & Value and understanding function & & 0.40 & .06 & $.34^{* *}$ & .58 \\
\hline & Social function & & 0.07 & .04 & .08 & .37 \\
\hline & Protective and enhancement function & & -0.08 & .05 & -.07 & .10 \\
\hline & Scope of justice & .57 & 0.52 & .06 & $.43^{* *}$ & .64 \\
\hline & Constant & & -0.57 & .30 & & \\
\hline
\end{tabular}

Note. $F_{\text {total }}=59.81^{* *} . d f=6 / 264$. All variables range from 1 to 6 , with a higher value indicating a stronger agreement.

${ }^{*} p<.05 .{ }^{* *} p<.01$

This is a well-known finding in the social conflict-solving context: ${ }^{73}$ psychological mediation with the basic principle "to enlarge the cake."74 It is difficult to widen the scope of justice and to include refugees, but it is necessary, to avoid a possible "clash of civilizations." 75

Since the aim is to promote integration and recruit greater numbers of volunteers, individual and controversial fairness judgments on the scope of justice should be taken seriously. Simple appeals to one's scope of justice might not be successful, but in view of the complexity of the subject, a public discourse should be held on justice questions, based on empirical data. Such a discourse might help to direct and productively tap into the emotional power of the current debate. Self-reflection on one's personal sense of fairness and judgment and behavioural attitudes seems to be necessary to overcome the political conflict caused by the refugee movement within the host country.

Moreover, the significance of the traditional functional variables includes recommendations for recruiting and keeping volunteers. These variables concern the value function (representing an altruistic concern for authors) and the understanding function (gaining new skills and knowledge and exercising them). Both variables are correlated very positively to volunteering and constitutes powerful motives.
The issue of moral values related to a basic concern for others (value function) should be addressed by encouraging the view that volunteering is a valuable way to gain and exercise new skills and knowledge (understanding function), such as by support of positive "testimonials."

Before discussing the theoretical implications, limitations should be mentioned in the critique by Hafer and Olson $^{76}$ of this kind of research. They pointed out that the mediation process should be investigated further. For this purpose, further variables should be taken into account longitudinally, such as the previously discussed perception of similarity, leading to empathy, between local inhabitants and refugees. Furthermore, the scope of justice variable needs further validation. This includes data sources other than self-reporting, such as assessments by peers or family members or by observing people in their interaction with refugees. Also, the problem of a lack of awareness about personal justice judgments could be dealt with by including additional methodological approaches in the form of more subtle measures of exclusion, such as reaction time methodologies. ${ }^{77}$ Moreover, the sample should be enlarged by including people who actively reject refugees. Together with a longitudinal design, these concerns would result in clear causal conclusions in the future. It would also be of great 
Table $\mathbf{3} \mathbf{b}$. Hierarchical multiple regression of willingness to volunteer on social desirability and group membership (step 1) (volunteers coded as 1), volunteer functions (step 2) and scope of justice (step 3)

\begin{tabular}{|c|c|c|c|c|c|c|}
\hline & Predictor & $R^{2}$ & $B$ & $S E(B)$ & ß & $r$ \\
\hline \multirow[t]{4}{*}{ Step 1} & Understatement of negative qualities & & -0.01 & .09 & -.01 & .04 \\
\hline & Exaggeration of positive qualities & & -0.12 & .07 & -.10 & -.13 \\
\hline & Group membership & 0.13 & 0.92 & .15 & $.35^{* *}$ & .36 \\
\hline & Constant & & 4.31 & .46 & & \\
\hline \multirow[t]{8}{*}{ Step 2} & Understatement of negative qualities & & 0.00 & .07 & .00 & .04 \\
\hline & Exaggeration of positive qualities & & -0.04 & .06 & -.04 & -.13 \\
\hline & Group membership & & 0.63 & .13 & $.24^{* *}$ & .36 \\
\hline & Career function & & -0.04 & .05 & -.05 & .06 \\
\hline & Value and understanding function & & 0.64 & .06 & $.55^{* *}$ & .59 \\
\hline & Social function & & 0.09 & .05 & .10 & .37 \\
\hline & Protective and enhancement function & 0.42 & -0.10 & .06 & -.08 & .11 \\
\hline & Constant & & 1.25 & .47 & & \\
\hline \multirow[t]{9}{*}{ Step 3} & Understatement of negative qualities & & 0.08 & .06 & .05 & .04 \\
\hline & Exaggeration of positive qualities & & 0.00 & .05 & .00 & -.13 \\
\hline & Group membership & & 0.55 & .11 & $.21^{* *}$ & .36 \\
\hline & Career function & & 0.02 & .05 & .02 & .06 \\
\hline & Value and understanding function & & 0.39 & .06 & $.33^{* *}$ & .59 \\
\hline & Social function & & 0.07 & .04 & .08 & .37 \\
\hline & Protective and enhancement function & & -0.06 & .05 & -.06 & .11 \\
\hline & Scope of justice & 0.56 & 0.53 & .06 & $.44^{* *}$ & .64 \\
\hline & Constant & & -0.93 & .47 & & \\
\hline
\end{tabular}

Note. $F_{\text {total }}=44.15^{* *} . d f=8 / 260$. All variables range from 1 to 6 , with a higher value indicating a stronger agreement.

${ }^{*} p<.05 .{ }^{* *} p<.01$

interest to find out whether the identity of refugees matters to volunteers. Have race, gender, national origin, or religion an influence on the scope of justice? These unanswered questions require further research.

Some of the criticism has already been rebutted by providing a clear definition and operationalization of the scope of justice construct, as well as taking alternative explanations into account and testing them explicitly. In addition, the social desirability bias issue has been addressed, but this does not fully solve the problems associated with selfreporting measures.

On a theoretical level, the results show that models of volunteering and justice research, with special focus on the scope of justice, can be fruitfully combined in the field of refugee aid. In this respect, the present study can be regarded as a pilot study aiming to apply existing constructs and research traditions on justice to the understanding of reactions to the current refugee movement and its potential for conflict, in view of the highly controversial reactions of those who are confronted with the influx in the host countries. Further in-depth research is needed to validate the findings, because in modern democracies, political measures can be implemented only if the majority of voters accept these measures. The recent political debate, in Germany and in many other countries, has shown how difficult and controversial such a discussion can become among different political parties but even within a single party, such as the CDU conservative party within the German coalition government. The scope of justice argument may enable this debate to take a more constructive, rational direction. And beyond the German borders, it shows on a scientific and political level how much perception of justice matters. The current migration movement, often disparagingly called a "refugee crisis," is a worldwide challenge that can be resolved only by 
constructive cooperation between countries, their political decision-makers, and the citizens they represent. Empirical research shows that the justice motive is a universal principle but that judgments passed on justice differ from one individual to the next. ${ }^{78}$ Judgments on the scope of justice with regard to the inclusion of refugees are of great importance for each individual's decision to volunteer and to accept refugees. This article therefore calls for a further examination, and possibly measures that contribute to an individual extension of the scope of justice.

\section{Notes}

1 We would like to thank Sophia Amschler and Mirjam Döbler for the recruitment of the sample and their support in conducting the study. We would like to thank Elizabeth Rogans for editing the text.

2 Federal Foreign Office, "Current Refugee Crisis-This Is What German Policy Is Doing: Tasks, Data and Facts" (Berlin, 2016).

3 Ibid.

4 Ibid.

5 Ibid.

6 Jenny Gesley, "Germany: The Development of Migration and Citizenship Law in Postwar Germany" (Washington, DC: Law Library of Congress, 2017).

7 Bundesamt für Migration und Flüchtlinge (BAMF) [Federal Office for Migration and Refugees], "(Spät-)Aussiedler in Deutschland: Eine Analyse aktueller Daten und Forschungsergebnisse [Ethnic German (re)settlers in Germany: An analysis of current data and research results]" (Berlin, 2013).

8 See Gesley, "Germany."

9 BAMF, "Aktuelle Zahlen zu Asyl [Current asylum numbers]" (Berlin, 2017).

10 Federal Office for Migration and Refugees, "Migration, Integration, Asylum" (Berlin, 2017).

11 Federal Foreign Office, "Current Refugee Crisis."

12 Federal Ministry of the Interior, "Welcome to Germany" (Berlin, 2014).

13 Serhat Karakayali and J. Olaf Kleist, "EFA-Studie: Sturkturen und Motive der ehrenamtlichen Flüchltingsarbeit (EFA) in Deutschland [eFA studies: Structures and motives of volunteering for refugees in Germany]" (Berlin, 2015).

14 Philipp Eisnecker and Jürgen Schupp, "Flüchtlingszuwanderung: Mehrheit der Deutschen befürchtet negative Auswirkungen auf Wirtschaft und Gesellschaft [Refugee migration: Majority of Germans fear negative outcomes for economy and society]," German Institute for Economic Research no. 8 (2016): 158-64.

15 Petra-Angela Ahrens, "Skepsis und Zuversicht [Skepticism and confidence]," Hannover, 2016), http://www.ekd.de/ fluechtlingsstudie-2016.pdf.
16 UNHCR, "UNHCR Viewpoint: 'Refugee' or 'Migrant' - Which Is Right?” (UNHCR: Geneva, 2016), http://www.unhcr.org/ news/latest/2016/7/55dfoe556/unhcr-viewpoint-refugeemigrant-right.html.

17 Federal Office for Migration and Refugees, "Current Asylum Numbers."

18 See J. Stacy Adams, "Inequity in Social Exchange," Advances in Experimental Social Psychology 2 (1965): 267-99.

19 Susan Opotow, "Seeking Inclusion and Pluralism: Two Exploratory Studies," Peace and Conflict: Journal of Peace Psychology 12, no. 4 (2006): 349-66.

20 Victoria M. Esses, John F. Dovidio, Lynne M. Jackson, and Tamara L. Armstrong, "The Immigration Dilemma: The Role of Perceived Group Competition, Ethnic Prejudice, and National Identity," Journal of Social Issues 57, no. 3 (2001): 389-412.

21 Linda J. Skitka and Faye J. Crosby, "Trends in the Social Psychological Study of Justice," Personality and Social Psychology Review 7, no. 4 (2003): 282-5.

22 See Federal Foreign Office, "Current Refugee Crisis."

23 See Federal Ministry of the Interior, "Welcome to Germany."

24 Sungkyu Lee, Sunha Choi, Laurel Proulx, and Jennifer Cornwell, "Community Integration of Burmese Refugees in the United States," Asian American Journal of psychology 6, no. 4 (2015): 333-41.

25 See Federal Ministry of the Interior, "Welcome to Germany." 26 E. Gil Clary, Mark Snyder, Robert D. Ridge, John Copeland, Arthur A. Stukas, Julie Haugen, and Peter Miene, "Understanding and Assessing the Motivations of Volunteers: A Functional Approach," Journal of Personality and Social Psychology 74, no. 6 (1998): 1516-30.

27 Ann Elisabeth Auhagen and Hans-Werner Bierhoff, eds., Responsibility: The Many Faces of a Social Phenomenon (London: Routledge, 2001).

28 Patrick Jiranek, Elisabeth Kals, Julia Sophia Humm, Isabel Theresia Strubel, and Theo Wehner, "Volunteering as a Means to an Equal End? The Impact of a Social Justice Function on Intention to Volunteer," Journal of Social Psychology 153, no. 5 (2013): 520-41.

29 Morton Deutsch, The Resolution of Conflict: Constructive and Destructive Processes (New Haven, Ст: Yale University Press, 1973).

30 Susan Opotow, "Predicting Protection: Scope of Justice and the Natural World," Journal of Social Issues 50, no. 3 (1994): 49-63.

31 See Opotow, "Seeking Inclusion and Pluralism."

32 See Opotow, "Predicting Protection."

33 Josh DeWind, "Alien Justice: The Exclusion of Haitian Refugees," Journal of Social Issues 46, no. 1 (1990): 121-32.

34 Donna K. Nagata, "The Japanese-American Internment: Perceptions of Moral Community, Fairness, and Redress," Journal of Social Issues 46, no. 1 (1990): 133-46.

35 Carolyn L. Hafer and James M. Olson, "An Analysis of Empirical Research on the Scope of Justice," Personality and Social Psychology Review 7, no. 4 (2003): 311-23. 
36 See Opotow, "Predicting Protection," 50.

37 Leo Montada and Angela Schneider, "Justice and Emotional Reactions to Victims," Social Justice Research 3, no. 4 (1988): 313-44.

38 Chris L.S. Coryn and Catherine Borshuk, "The Scope of Justice for Muslim Americans: Moral Exclusion in the Aftermath of 9/11," Qualitative Report 11, no. 3 (2006): 586-604.

39 Aline Lima-Nunes, Cicero Roberto Pereira, and Isabel Correia, "Restricting the Scope of Justice to Justify Discrimination: The Role Played by Justice Perceptions in Discrimination against Immigrants," European Journal of Social Psychology 43, no. 7 (2013): 627-36.

40 See Hafer and Olsen, "Analysis of Empirical Research."

41 See Jiranek, "Volunteering as a Means to an Equal End?"

42 See Opotow, "Predicting Protection."

43 See Hafer and Olson, "Analysis of Empirical Research."

44 See Opotow, "Predicting Protection."

45 See Hafer and Olson, "Analysis of Empirical Research."

46 John Wilson, "Volunteering," Annual Review of Sociology 26, no. 1 (2000): 215-40.

47 See Skitka and Crosby, "Trends in the Social Psychological Study of Justice."

48 See Clary et al., "Understanding and Assessing the Motivations of Volunteers."

49 Daniel Katz, "The Functional Approach to the Study of Attitudes," Public Opinion Quarterly 24, no. 2 (1960): 163-204.

50 See Clary et al., "Understanding and Assessing the Motivations of Volunteers."

51 Barbara J. Houle, Brad J. Sagarin, and Martin F. Kaplan, "A Functional Approach to Volunteerism: Do Volunteer Motives Predict Task Preference?," Basic and Applied Social Psychology 27, no. 4 (2005): 337-44.

52 Stefan Tomas Güntert, Isabel Theresia Strubel, Elisabeth Kals, and Theo Wehner, “The Quality of Volunteers' Motives: Integrating the Functional Approach and SelfDetermination Theory," Journal of Social Psychology 156, no. 3 (2016): 310-27.

53 See Auhagen and Bierhoff, Responsibility.

54 Cicero Pereira, Jorge Vala, and Rui Costa-Lopes, "From Prejudice to Discrimination: The Legitimizing Role of Perceived Threat in Discrimination against Immigrants," European Journal of Social Psychology 40, no. 7 (2010): 1231-50.

55 Leo Montada, Elisabeth Kals, and Ralf Becker, "Willingness for Continued Social Commitment: A New Concept in Environmental Research," Environment and Behavior 39, no. 3 (2007): 287-316.

56 See Clary et al., "Understanding and Assessing the Motivations of Volunteers."

57 Christoph J. Kemper, Constanze Beierlein, Doreen Bensch, Anastassiya Kovaleva, and Beatrice Rammstedt, "Eine Kurzskala zur Erfassung des Gamma-Faktors sozial erwünschten Antwortverhaltens [A short scale measurement of the gamma factor of socially desirable answering behavior]"
(Köln: GESIS-Leibnitz-Institut für Sozialwissenschaften, 2012).

58 Jeannette Oostlander, Stefan Tomas Güntert, Susan van Schie, and Theo Wehner, "Volunteer Functions Inventory (VFI): Konstruktvalidität und psychometrische Eigenschaften der deutschen Adaptation [Volunteer Functions Inventory (VFI): Psychometric properties of the German adaptation and construct validation]," Diagnostica 60 (2014): $73-85$.

59 See Lima-Nunes et al., "Restricting the Scope of Justice."

60 See Ahrens, "Skepticism and Confidence."

61 See Esses et al., "Immigration Dilemma."

62 See DeWind, "Alien Justice."

63 See Federal Foreign Office, "Current Refugee Crisis."

64 See Opotow, "Seeking Inclusion and Pluralism," 355.

65 C. Daniel Batson, Tricia R. Klein, Lori Highberger, and Laura L. Shaw, "Immorality from Empathy-Induced Altruism: When Compassion and Justice Conflict," Journal of Personality and Social Psychology 68 (1995): 1042-54.

66 Elisabeth Kals and Markus Müller, "Education for Sustainability: Moral Issues in Ecology Education," In Handbook of Moral and Character Education, ed. Larry Nucci, Tobias Krettenauer, and Darcia Narvaez, 471-87 (New York: Routledge, 2014).

67 Susan Opotow, Janet Gerson, and Sarah Woodside, "From Moral Exclusion to Moral Inclusion: Theory for Teaching Peace," Theory into Practice 44, no. 4 (2005): 303-18.

68 Daniel Geschke, "Prejudice against and Discrimination of Asylum Seekers: Their Antecedents and Consequences in a Longitudinal Field Study" (PhD diss., Friedrich-SchillerUniversität Jena, 2007).

69 Robert B. Zajonc, "Attitudinal Effects of Mere Exposure," Journal of Personality and Social Psychology 9, no. 2 (1968): $1-27$.

70 See Opotow, "Seeking Inclusion and Pluralism."

71 Leo Montada, "Doing Justice to the Justice Motive," in The Justice Motive in Everyday Life, ed. Michael Ross and Dale T. Miller, 41-62 (Cambridge: Cambridge University Press, 2002).

72 See Esses et al., "Immigration Dilemma."

73 Elisabeth Kals and Jürgen Maes, eds., Justice and Conflicts: Theoretical and Empirical Contributions (Berlin: Springer Science \& Business Media, 2012).

74 Elisabeth Kals, Kathrin Thiel, and Susanne Freund, "Workplace Mediation: Searching for Underlying Motives and Interests," in Advancing Workplace Mediation through Integration of Theory and practice, ed. Katalien Bollen, Martin Euwema, and Lourdes Munduate, 39-53 (New York: Springer International Publishing, 2016).

75 Samuel P. Huntington, The Clash of Civilizations and the Remaking of World Order (London: Simon \& Schuster, 1996).

76 See Hafer and Olsen, "Analysis of Empirical Research."

77 Ibid.

78 See Montada, "Doing Justice to the Justice Motive." 
Elisabeth Kals is professor of social and organizational psychology at the Catholic University of Eichstätt-Ingolstadt, Germany, and associate member of the Centre of Flight and Migration at Eichstätt University. The author may be contacted at elisabeth .kals@ku.de.
Isabel Theresia Strubel is a doctoral candidate in social and organizational psychology at the Catholic University of Eichstätt-Ingolstadt, Germany. The author may be contacted at isabel.strubel@gmail.com. 